\title{
Bullet impacts and built heritage damage 1640-1939
}

\author{
L. Mol ${ }^{1 *}$ (D) and M. Gomez-Heras ${ }^{2,3}$
}

\begin{abstract}
Conflict damage to heritage has been thrust into the global spotlight during recent conflict in the Middle East. While the use of social media has heightened and enhanced public awareness of this 'cultural terrorism', the occurrence of this type of vandalism is not new. In fact, as this study demonstrates, evidence of the active targeting of sites, as well as collateral damage when heritage is caught in crossfire, is widely visible around Europe and further afield. Using a variety of case studies ranging from the 1640s to the 1930s, we illustrate and quantify the changing impact of ballistics on heritage buildings as weaponry and ammunition have increased in both energy and energy density potential. In the first instance, this study highlights the increasing threats to heritage in conflict areas. Second, it argues for the pressing need to quantify and map damage to the stonework in order to respond to these challenges.
\end{abstract}

\section{Introduction}

Armed warfare has wreaked havoc on the built environment for centuries. Major periods of conflict, such as the sacking of Athens by the Persians and the targeted destruction of major sanctuaries in $480 \mathrm{BC}$, provide clear historical precedents in the ancient world [1]. Within the last century, Europe-wide destruction of dwellings during the world wars as part of bombings [2] may be compared with the dramatic deterioration of statues and buildings in the Angkor Wat compound during the 20-year Khmer Rouge-driven conflict (through post-conflict neglect as much as direct damage [3]). Such instances have left dramatic scarring on the built environment. While the extensive destruction of sites through the use of explosives has dominated current international headlines, relatively little is reported about the smaller scale destruction such as ballistic impacts (bullets) and shrapnel which can permanently scar and destabilise built heritage. Famous examples of this type of heritage damage include sites such as the Dublin Post Office (1916 Easter Rising impacts) and the bullet hole riddled walls of Budapest (1956 Hungarian Uprising), which are now commemorative sites in their

\footnotetext{
*Correspondence: lisa.mol@uwe.ac.uk

1 Department of Geography and Environmental Management, University of the West of England, Frenchay Campus, Coldharbour Lane, Bristol BS16 1QY, UK

Full list of author information is available at the end of the article
}

own right. Conflict damage can therefore be associated with a changed status as a heritage site, turning a previously little-noticed site into a monument or providing an additional layer of 'commemorative value' to an existing heritage site. The commemorative role of heritage in post-conflict social reconstruction can be supportive, allowing the surviving population to rebuild their cultural identity, provided there is suitable management in place to facilitate reconciliation rather than encourage continued aggravation towards the 'other side' [4]. However, the complexities of adding a new commemorative layer-i.e., the damage sustained during the conflict-to existing heritage such as monuments and places of worship require a more specific approach to the wider conversation about heritage and conflict: war-damaged heritage sites must instead be specifically targeted by conservation and restoration efforts to preserve both the heritage and, if possible, the new heritage in the form of conflict damage. The articulation and practice of a conservation strategy which is sensitive to these shifting concerns therefore requires a sound scientific understanding of the material damage caused by ballistic impacts over an extended period.

Developing such a strategy requires an interdisciplinary awareness of the multiple meanings of heritage and conflict. In the first instance, conflict damage can be used as an excuse to facilitate widespread clearing of heritage sites. For example, in the years after World War II the city of 
Bristol saw the war damage as a 'golden opportunity' to facilitate the introduction of large scale infrastructure, as journalist Max Barnes in the Evening Post (25th September 1942) argued: "Probably you think there are too many arty-crafties and architectural windbags coming down to Bristol advising the Corporation to waste your rates on preserving tatty old disused church towers." The desired destruction of the majority of religious buildings, including as churches and chapels, in favour of shopping centres was met with opposition at the time. As a reader of the Bristol Evening Post (18th June 1946) lamented: "It is sure a tragedy... that this historic landmark [Broadmead Chapel] should fall a victim to the march of progress. Progress, how many crimes have been perpetrated in thy name?" Even such brief exchanges suggest that heritage remains in need of a defender post-conflict as much as it is during the conflict, especially when it has sustained significant conflict damage. Therefore conservation strategies for conflict damage on heritage should consider both [1] prevention of further damage through long-term deterioration and [2] prevention of reckless replacement of heritage. This includes prevention of removal of original material when the damage does not threaten overall structure stability. Careful conservation of these sites therefore requires a quantitative knowledge of the physical damage inflicted by ballistics, within the context of the date of impact and the weaponry used, which can be applied alongside qualitative understandings of shifting cultural value.

Damage to heritage in conflict zones can be inflicted either when the heritage is simply standing in the way of a conflict, getting caught in the crossfire, or in a more targeted way such as vandalism, which includes any destruction of heritage that can be denounced as barbarous, ignorant, or inartistic treatment [5]. This type of destruction contrasts with iconoclasm, which refers to the opposition to, and destruction of, religious images and sites as an act to overthrow the religious beliefs of others and physically and metaphorically dismiss them as fallacious or superstitious [5]. In recent years, ideology-driven destruction of heritage during conflict has been particularly associated with the Middle East and the activities of Daesh/So-Called IS, and the rise of what is now termed 'cultural terrorism' $[6,7]$. The coming together of physical damage and social media has arguably increased the profile of heritage sites in conflict areas [8,9]. What is of particular concern in context of this increasing targeting of heritage, as this research illustrates, is that the tools with which this destruction can be inflicted are increasing in strength and availability. Whereas the results discussed in Case Study 1 show that the musket balls used in the 17th century were relatively non-destructive to wider structural stability, the Mauser guns used in the 20th century have (Case Study 4) left a network of fractures throughout the stone that threaten not only the direct impact site but also the wider stone ledges. This accelerating potential to inflict damage, when considered alongside the sort of ideologically-driven destruction outlined very briefly above, requires a careful analysis of the impact of ballistics on stone surfaces. In this research we explore this increasing damage curve by contrasting historic ballistic impacts.

To assess this increasing damage inflicted on heritage by ballistics we present four very different case studies that all share a common scarring by ballistics sustained during conflict and/or created by vandalism associated with conflict. These illustrate the wide ranging occurrence of this type of damage and highlights the complexities that are created by the high-velocity/high-energy impact of a bullet upon a stone surface. Despite the prevalence of this type of damage in our built environment, relatively little is known about the short- and long-term implications of ballistic impacts [10]. What is even more concerning is the rapid pace of development of ammunition and the ever-increasing risk it poses to heritage. To highlight this increasingly-destructive nature of ballistics, and the associated concerns for heritage conservation, the case studies here have been placed in chronological order: (1) Accidental damage in the Civil War in Great Britain and Ireland (1642-1651) (Powick, Gloucestershire), (2) Ideology-driven damage in the Civil War in Great Britain and Ireland (1642-1651) (Oxford, Oxfordshire) (3) Colonialism and vandalism during the Lalangibalele uprising (1873-1874) in South Africa (uKlahamba Drakensberg); and (4) Spanish Civil War (1936-1939) in Madrid. We utilise the Case Studies 1, 2 and 4 to highlight quantification of the material damage incurred during conflict. Due to the sensitive nature of the site it was not possible to take measurements of surface deterioration for Case Study 3, but the variability in angle at which the rock art was shot at is used here to illustrate the complex nature of ballistic impacts as well as the progression from musket impacts (case studies 1 and 2) to matchlock rifles.

\section{Case studies 1 and 2: civil war in Great Britain; ideology-driven and collateral damage (1642- 1651)}

While the current scale and global awareness of destruction of heritage in the Middle East is unprecedented, it is by no means the first occurrence of ideology-driven targeted destruction of buildings and objects. Some authors assume the French Revolution was a milestone in the history of art destruction [5], but there are numerous instances of ideology-driven damage throughout history. These not only include the above-discussed iconoclasm, but also "spolia", which includes the destruction, even of entire buildings, often with a symbolic purpose of destruction of the people who built them. This has 
been commonplace in Europe since Roman times [11]. Iconoclasm and "spolia" therefore share an ideologydriven destructive purpose, but iconoclasm is eminently focused on the religious resonances of the destructive act, while "spolia" includes a more general societal attack. For instance, during the Civil War in Great Britain and Ireland, active targeting of religious sites (in particular those elements which were most heavily contested such as images of saints and altar rails [12]) by Parliamentarian groups as well as local pressure groups was part and parcel of the wider conflict. In each instance, the historical relevance of the heritage is deeply connected with the destruction itself, with the ballistic impacts providing an essential element of the wider narrative.

In this example, religious artefacts destruction has become not only a way of destroying religious artefacts (iconoclasm), but also a way of expressing the symbolic destruction of a previous regime (spolia). For example, Budd [13] notes that the deliberate destruction of the Cheapside Cross in London (also during the Civil Wars of the 1640s) was as much an act of popular religious expression as a symbolic statement about the allegiance of London to the reforming cause. The religious ideology behind the act is so entwined with political allegiance that the two are virtually inseparable, as was the case during the Civil War [14]. In these instances, damage to heritage gains further historical relevance, and makes a strong case for preservation of the damaged sites. Such targeted destruction was not restricted to the London area, but took place wherever Parliamentarians felt emboldened either through local pressure groups or the presence of the Parliamentarian army. In the case of Powick Church (Case Study 1), the site became collateral damage as Royalists troops using the elevated position as a look out were shot at by Parliamentarian troops, which has left a collection of musket ball impacts on the tower. The damage to the second site (Case Study 2) was far more deliberate, as the statue of St. Mary was targeted by the Parliamentarian troops to eradicate doctrinally-objectionable religious imagery, leaving it pockmarked with musket ball impacts and removing the nose altogether. Once again, the survival of such damage into the present day and their historical resonances pose important challenges to heritage conservation well beyond qualitative understanding.

\section{Case study 1: Powick Church, Gloucestershire, UK}

St. Peter's Church is situated about two miles south-west of Worcester (Gloucestershire, UK) in Powick. Parts of the building date back as far as the 12th century though the church in its current form was largely established in the 14th and 15th century, including the tower referred to in this study [15]. The objects of interest for this study are the bullet impacts on the tower, a result of the fighting on the advance of Parliamentary troops on 3 September 1651. Royalist

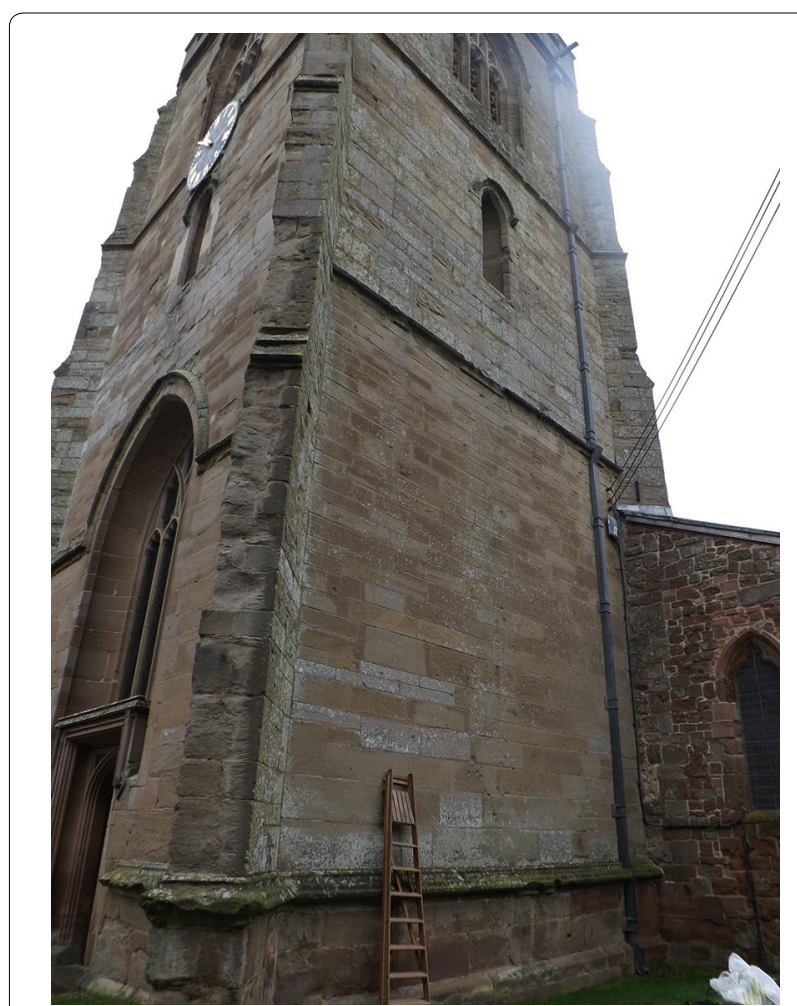

Fig. 1 Powick Church tower wall damaged by musket-ball shots

Scottish troops exploited the elevated position of the church to observe the surrounding countryside, but were discouraged from continuing to do so by musket-ball shots fired by the approaching Parliamentarian troops ( [16] p. 75-78) using either a matchlock or a flintlock musket [17]. Figure 1 shows an overview of the affected wall. Though not clearly visible in this image, the majority of the musket-ball pockmarks are located at the height of the ladder and above.

A closer look at these pockmarks shows the relatively limited damage 17th century ammunition inflicted on sandstone (see Fig. 2); the indentures of the musket balls are visible as a concavity in the stone surface with a deeper direct impact centre surrounded by a more shallow removal of materials at the near-surface.

To understand what effect ballistic impacts from the 17th century have on the deterioration of the stone, rock surface hardness (RSH) measurement surveys were carried out across nine impacted building blocks (see Fig. 3). These blocks represent a range of impact densities, from a single impact on a block (block 8 ) to six impacts within short distances of each other (block 6).

\section{Methodology}

Rock surface hardness As several studies have demonstrated [18-21], RSH can be used as a key-indicator of the 

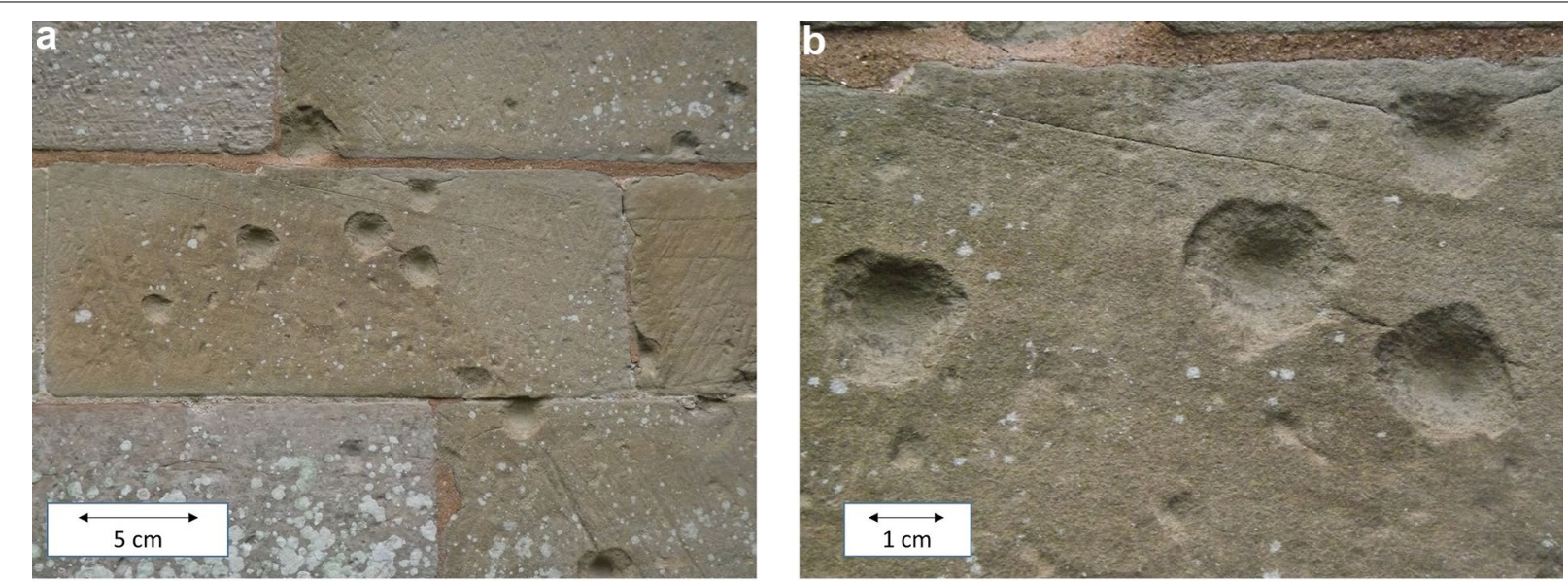

Fig. 2 a Ballistic impacts on the tower of St Peter's Church in Powick; $\mathbf{b}$ close up of ballistic impacts shown in (a)

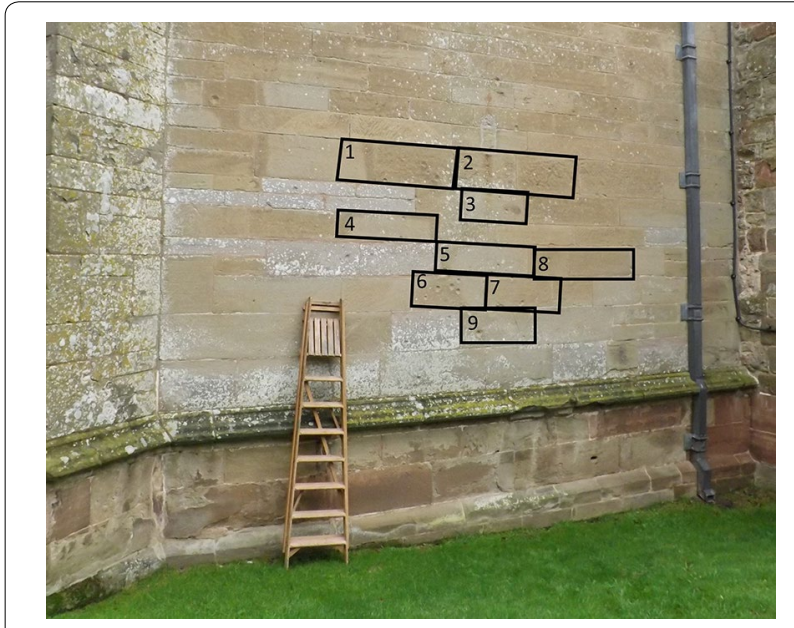

Fig. 3 Measured sites on Powick Church, including case study blocks 3,5 and 6 in the centre of the general impacted area

degree of weathering of a surface. In this study, an Equotip 3 with a D-type probe was used to map variations in weakening of the stone surface. This equipment was originally developed for the testing of metals [22], but is now used in both natural settings [23, 24] and the built environment [25]. The surface hardness is measured through rebound of a $3 \mathrm{~mm}$ diameter spherical tungsten carbide test tip against the rock surface. This tip is mounted in an impact body and impacts under spring force against the test surface from which it rebounds [26]. The velocity before impact $(V$,$) and after$ impact $(V 2)$ are measured automatically and displayed as a ratio $(V 2 / V, \times 1000)$ which is denoted by the unit ' $\mathrm{L}$ ', or Leeb unit [27]. The nine blocks were each subdivided into 50 measurement points, noting distance from nearest bullet impact.

Surface hardness interpolation (Kriging) ArcGIS (ArcMap 10.4) was used to map the most likely distribution of surface hardness. All measurements were plotted on a georeferenced image of the individual building block, which was then used to carry out Kriging ordinary spherical interpolation of most likely surface hardness measurement distribution. All test blocks were plotted both using a general range that covered all measurements (100-400 Leeb hardness values), to facilitate cross-block comparison.

\section{Results}

For this study, three of the blocks were selected for further analysis, representing low number of impacts (block 3 ), mixed small and large impacts (block 5) and high density of large impacts (block 6) to illustrate spatial patterns in surface hardness associated with ballistic impacts. Figure 4 shows the results for all three blocks.

As illustrated by Fig. 4a, relatively little variation in surface hardness measurements is exhibited on block 3 , which received only three large ballistic impacts. In fact, the areas directly surrounding the impacts appear a little more robust than the areas further removed from the impact. The majority of the deterioration appears to have taken place towards the bottom-left of the block, which could be associated with deterioration patterns often observed in sandstone building stone based on moisture movement through the blocks [28] at the intersection between porous stone and mortar [29]. The more remarkable observation is that the areas where the bullets have impacted appear to have strengthened, rather than weakened. This same pattern is repeated at block 5 , where areas of most severe weakening are outside of the impact zones. It is likely that this is a function of the flexural strength of the sandstone and the nature of a musket ball, which lacks the energy density of point-tipped contemporary projectiles, such as the $7.62 \times 39 \mathrm{~mm}$ bullets commonly used in AK-47 and other assault rifles, 


\section{Block 3}
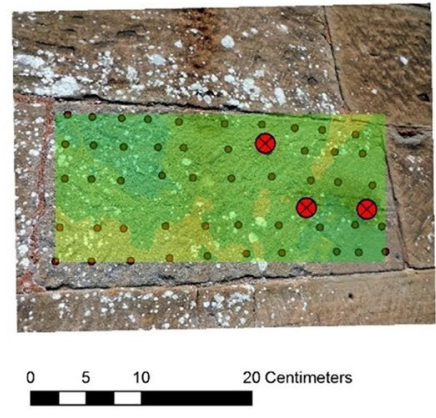

a

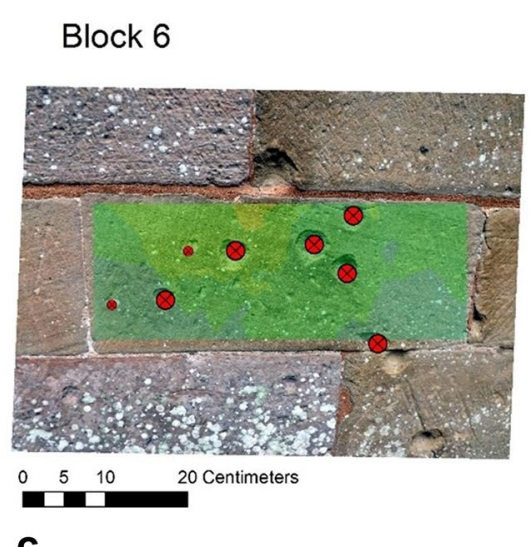

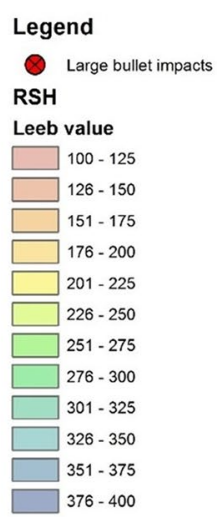

Legend

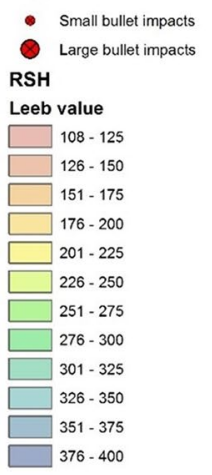

C
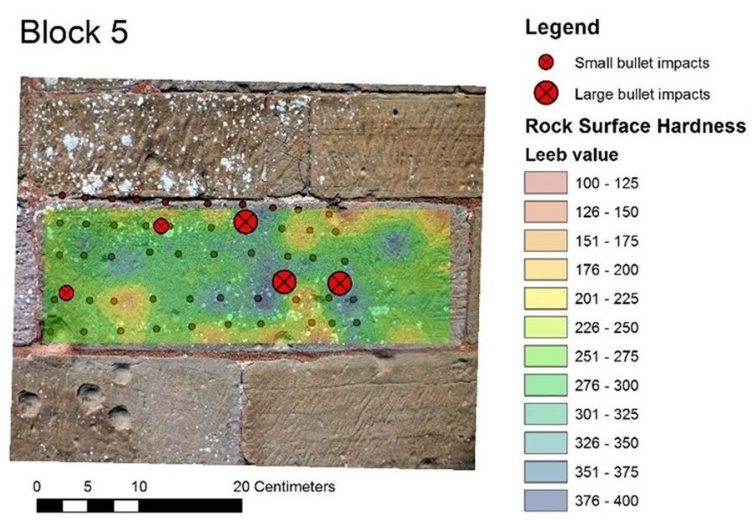

b

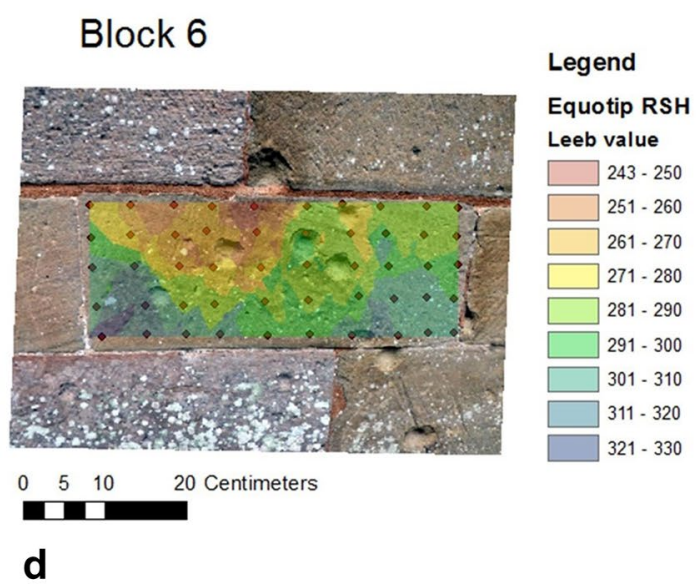

Fig. 4 Kriging inferred distribution of surface hardness variation and bullet impacts plotted for block $3 \mathbf{a}$ block $5 \mathbf{b}$ and block $6 \mathbf{c}$. $\mathbf{d}$ Values for block 6 have been plotted on a limited scale (243-330) to highlight variation in values associate with bullet impacts which may not be evident at a large scale

as illustrated in Fig. 5. The matchlock muskets used in the Civil War only had an effective range of $183-380 \mathrm{~m}$ and swiftly lost velocity [30] having reached a maximum speed of $180 \mathrm{~m} / \mathrm{s}$ [31]. As Powick Church is in an elevated position it is likely that the Parliamentarian soldiers had to fire up slope, which would have further decreased the damage potential of the ballistics.

Upon impact, the ballistic has noticeably removed some of the surface, and left the bullet imprints investigated here. Within this newly exposed surface the clay content within the sandstone matrix will have compacted and realigned itself with the impact, thus reducing permeability and susceptibility of the material to deterioration processes. While it was not possible to sample the stone at this listed Grade I building, this principle has been tested using similar sandstone [10]. Thin section analysis showed that at the point of impact of a low-calibre bullet, the clay minerals in the cement matrix realigned with the direction of impact (see Fig. 6). While there are differences between the ballistics used during

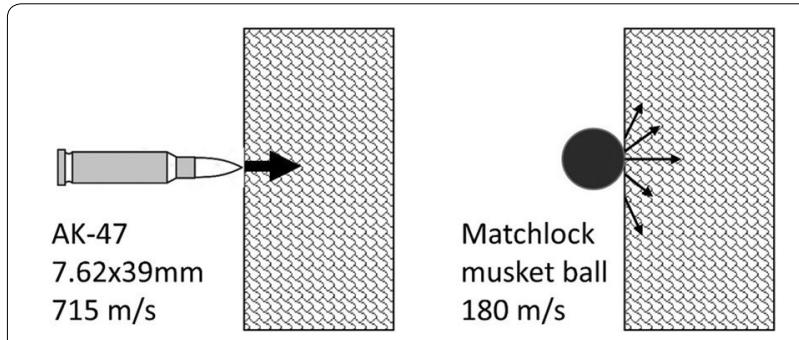

Fig. 5 A simple illustration of energy density and dispersal in an AK-47 impact vs a Matchlock musket ball impact

the Civil War and the ballistics used in this test, a.22 calibre lead bullet is soft and deforms easily [32] reaching a maximum of $275-365 \mathrm{~m} / \mathrm{s}$, thus also falls into the 'low impact' group of ballistics, penetrating relatively little into the impacted surface [33]. We hypothesise that the relative strengthening of the surface within the impact areas observed on Powick Church is due to realignment of the clay matrix within the sandstone surface, 


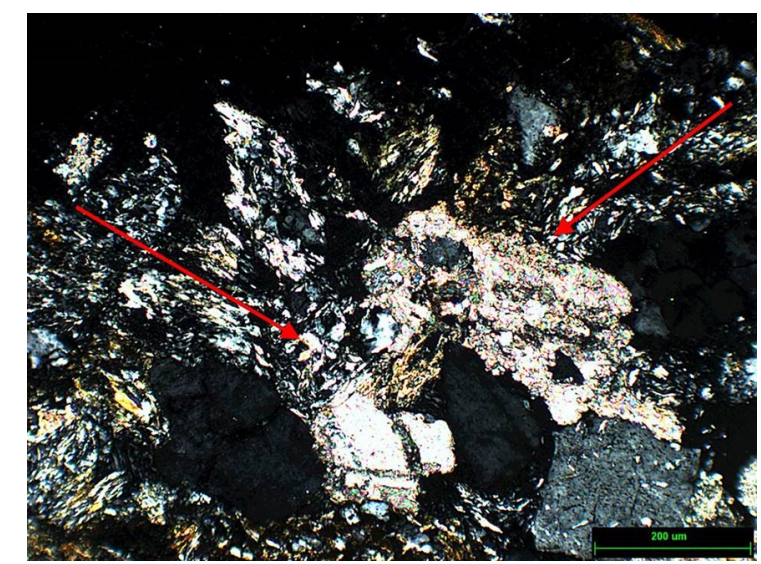

Fig. 6 Realignment of clay matrix within sandstone upon impact of a ballistic

in a process comparable to that observed in the simulation tests of .22 calibre lead bullets on a similar sandstone surface in previous research [10]. Surprisingly, this could indicate that a singular impact point from a lowimpact projectile (such as a musket ball) could actually be stronger than the material surrounding it.

However, when ballistic impacts are closely spaced together there does appear to be a more focussed deterioration, as demonstrated in block 6 analysis (Fig. 4c, d). As shown in Fig. 4d, which was plotted on a limited Leeb hardness scale to reflect variations within the individual block, the areas immediately surrounding the large impacts have deteriorated further (Leeb values ranging from 243 to 290) than the areas towards the bottom of the block (Leeb values ranging from 280 to 330). This leads to the hypothesis that low-impact ballistic damage in principle does not cause extensive weakening of the surface; in fact, a singular impact could exhibit strengthening rather than weakening of the surface, though this is measured through about 350 years of exposure, but that clusters of low-impact damage do lead to enhanced deterioration of structural strength of the block and therefore need to be assessed as a potential conservation risk.

\section{Case study 2: ideology-driven damaging of St. Mary the Virgin, Oxford, UK}

In this case study, deliberate damage to build heritagerepresenting ideology-driven "cultural terrorism" and its resultant damage by the Parliamentarian troops outlined at the beginning of "Case studies 1 and 2: civil war in Great Britain; ideology-driven and collateral damage (1642-1651)"-is contrasted with the unintentional damage to heritage caught in crossfire illustrated in the Case Study 1. This case study investigates the deliberate damage to St. Mary the Virgin on the High Street in
Oxford, which is the University Church of the University of Oxford. In contrast with Case Study 1, these impacts on the limestone statue have not been left exposed but instead have been repaired using lime mortar. This case study therefore also illustrates problems in accurately assessing damage when infill of, or other 'restorative work' on, the impact area has taken place.

Between 1644 and 1646 Oxford was under siege by the Parliamentarian troops, a response to the entrenchment of the court of Charles I in the city and its new status as the de facto capital. This new status transformed city life as the infrastructure and population were strained by the pressures of the incoming troops and new demands of maintenance and supply-lines [34]. This situation changed when, on 24 June 1646, Royalist troops withdrew from the city ahead of an occupying Parliamentarian force [35]. With the arrival of the Parliamentarians a new, iconoclastic stance took form on the streets of Oxford, manifesting itself in an antagonistic approach to the city's places of worship. While the destruction of religious icons has at times been exaggerated in historical discussion of the Parliamentarian armies, it was a real and meaningful phenomenon, part of a wider official drive against images [36]. It is thought, for instance, [37] that the University Church on the Oxford High Street, and in particular the portico containing the statue of the Virgin Mary and Child, did not escape this destructive ideology (see Fig. 7a-c). At the time the destruction took place the portico itself was relatively new, built in 1637 by Nicholas Stone. It has since been repaired in 1865 [38], which included infill of the bullet impacts with lime mortar and reconstruction of the nose, following initial repair in 1662 [39]. As such, discussion of conservation efforts of this heritage must incorporate the subsequent repair works within the historical context of this initial, ideology-driven act of destruction and its place in the historical narrative. In the remainder of this section, the deliberate destruction of heritage during conflict will be discussed, as well as the impact of repairs on accurate damage assessment.

\section{Methodology}

As in Case Study 1, surface hardness was used to determine relative deterioration of the surface. This was quantified using the same Equotip 3 with D-type probe. Sampling was directed by the features of the statue, e.g. chin, nose, crown, neck, etc. (Fig. 7e), and with notes taken on sections where supposed ballistic impacts were located (Fig. 7d). Where an impact had taken place the area directly adjacent to the repairs was measured, rather than on the infill of the indentation left by the ballistic, which would merely have measured the strength of the lime mortar rather than the damage to 

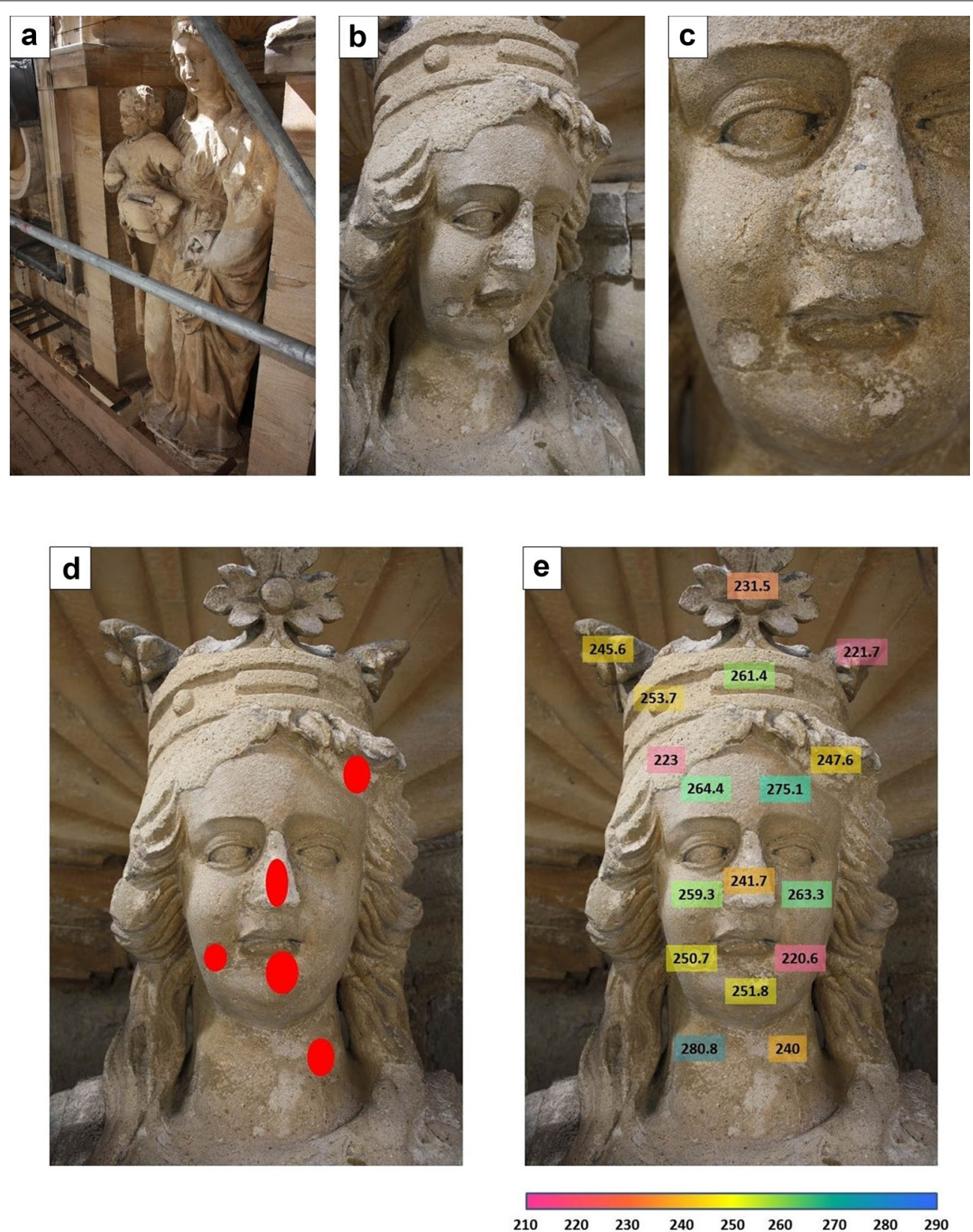

Fig. 7 a Overview photo of the statue. $\mathbf{b}$ Damage to head and neck of the statue. $\mathbf{c}$, $\mathbf{d}$ Sites of suspected ballistic impacts. e Rock Surface Hardness (Leeb values) results, $n=10$ per site

stonework. The mean hardness value, presented in the figures, was calculated using 10 repetitions of impact measurements at each sample site, following previously established procedure of using multiple measurements in one surface area to offset outliers $[24,40,41]$.

\section{Results}

As shown in Fig. 7c, d, there is no obvious visual pattern of accelerated deterioration of the impact zones. On the neck of the statue, the impacted side (right, Leeb value 240) shows noticeably lower Leeb values than the non-impacted side (left, Leeb value 280.8). This trend reverses on the chin and lower cheek, where impacted areas measured were higher on the impacted side than the non-impacted side. However, when the variability of the measurements is taken into account as an indicative factor in weathering progress [42] with higher standard deviations indicative of relatively more intense weathering of the surface, three distinct groups of measurements emerge; as Fig. 8 shows, group 1 consists of high 
variability measurements (standard deviation range 61 to 80) indicating a further developed weathering pattern, and encompasses the more vulnerable sections such as the crown and the intricate portico. These intricate features are particularly vulnerable to weathering processes because of their relatively high surface to volume ratio, as noted by de'Gennaro et al. [43]. Group 2 consists of impacted areas, which are mainly located in the less vulnerable sections of the statue such as the neck, with smooth carved surface and a higher volume to surface ratio. Group 3 consist of similar features to Group 2, lessvulnerable areas, but without the presence of impacts.

The clustering of the impacted areas of Group 2 (mean Leeb value 246.36), which are in sections of the statue comparable to those in Group 3 (mean Leeb value 260.75 ), indicates that an overall deterioration of surface structure where a matchlock musket ball has hit at this site led to a reduction in mean Leeb value of $5.52 \%$. The standard deviation does not vary noticeably between the two groups, respectively 51.06 (Group 2) and 51.71 (Group 3), indicating that difference between the two groups is based on a general lowering of the Leeb value where impacts have taken place, rather than an increase in measurement variability.

Difficulties in accurately assessing the long-term consequences of these ballistic impacts is exacerbated by the presence of the repairs carried out in 1865; the addition of lime mortar to the cavities in limestone of the statue obscure the impact cavity and prevent measurements of the impact surface. Furthermore, later addition of alien material has been noted to accelerate deterioration in heritage structures (e.g. [44]), which needs to be accounted for when assessing the relative impact of ballistics on surface deterioration. As this limestone statue was repaired using lime mortar it is assumed here that the elastic modulus and moisture retention behaviour was compatible and that therefore the reduction

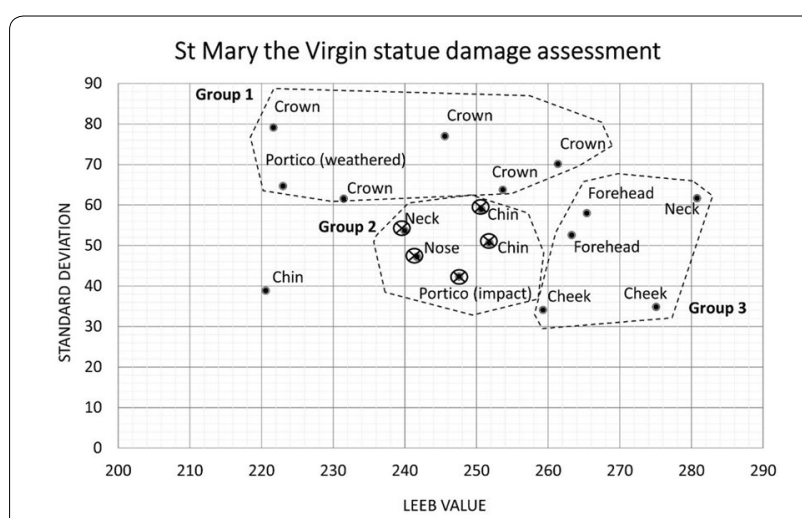

Fig. 8 Plot of mean Leeb values and Standard Deviation per measured site. $\mathrm{N}=10$ for each site in surface strength can be contributed to the ballistic impacts. However, experimental research is needed to conclusively quantify the influence of alien material introduction on impact site deterioration.

\section{Colonialism and cultural vandalism}

The erosion of cultural pride under a colonial regime as a country-wide phenomenon has been remarked upon by scholars such as Taruvinga and Ndoro [45], as indigenous sites and art often faced neglect if not outright vandalism within colonial regimes. The disregard for indigenous culture during periods of colonial rule as well as the deliberate destruction of culture to establish dominance are themes that resonate in conflicts throughout history in what Bevan considers "calculated acts of cultural annihilation" [46]. In particular, in times of conflict site security and heritageprotective legislation can be either ineffective or unenforced; this is illustrated by the case study presented here, where boredom of troops superseded any awareness of the cultural importance of the sites they targeted for sport. The protection of indigenous culture in particular can be at risk when an external force is in conflict with the local population, increasing the risk of vandalism and neglect. In this case study, we explore vandalism during the 19th century, when weaponry and ammunition had evolved from the matchlock muskets discussed in case studies 1 and 2 to the more sophisticated percussion lock rifle.

\section{Case study 3: damage to San rock art, Giant's Castle Main Cave, Drakensberg South Africa}

The Main Caves at Giant's Castle in the uKhahlambaDrakensberg Park of KwaZulu-Natal, forms part of an UNESCO world heritage site [47]. These panels were painted starting approximately 3000 years ago, and were subsequently enhanced and expanded over the centuries following, by the San who inhabited the interior of southern Africa until approximately 1870 [48]. During the Langalibalele uprising, British troops under the command of Captain Barter entered the area and took refuge in the Main Caves in autumn 1873 on their way to the projected battle site of Bushman's River Pass (KZN Wildlife, pers comm. 04/04/2017), [49]. This troops formed part of a larger campaign led by Major Durnford and was to cross the Giant's Castle Pass to join with the other troops travelling through the Champagne Castle Pass under Captain Allison and troops from the east led by Major Durnford himself [50]. Captain Barter's troops took refuge for the night and built a shelter under the rock overhang (Fig. 9) Armed with, likely, percussion-lock muskets [51] the troops evidently decided to use the San Rock Art for target practice (Fig. 10a). This blatant vandalism focussed predominantly on, but not restricted to, the main panel (Fig. 10b), spanning a number of figures including two 


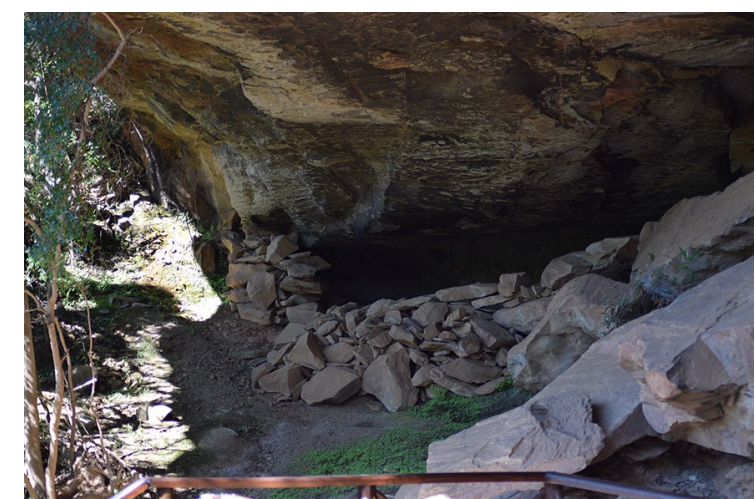

Fig. 9 Shelter built by Captain Barter's troops within the Main Cave. The Rock Art is situated on the rock face to the right of the shelter (not visible in this image)

large and one small therianthropes (mythical being which is part human, part animal) and hartebeests (African antelopes), as well as hunters carrying bows and arrows (Dr Rachel King, pers comm 24/11/2017).
Due to the sensitive physical and social nature of San Rock Art it was not possible to acquire measurements at this site. However, visual analysis shows that the soldiers were likely standing directly in front of the left hand side of the large panel, shooting directly at the large eland (Fig. 10d) where energy appears to have dissipated from a central point, as illustrated in Fig. 11a. In contrast, the therianthropes (Fig. 9c) appear to have been shot at from a more sideways angle (approximately $135^{\circ}$ ), as evidenced by the elongated impact (Fig. 11b). Visual comparison indicates that bullets shot at this kind of angle tend to 'gouge' the rock face, leaving a deeper indentation than those bullets shot at a $90^{\circ}$ angle and potentially leaving the surface more vulnerable to deterioration.

\section{0th Century conflict}

A century after the incidents illustrated in Case Study 3, a civil war broke out in Spain (1936-1939) which saw the Republicans fight against the Nationalists led by General Franco. This conflict included a besieging of Madrid,
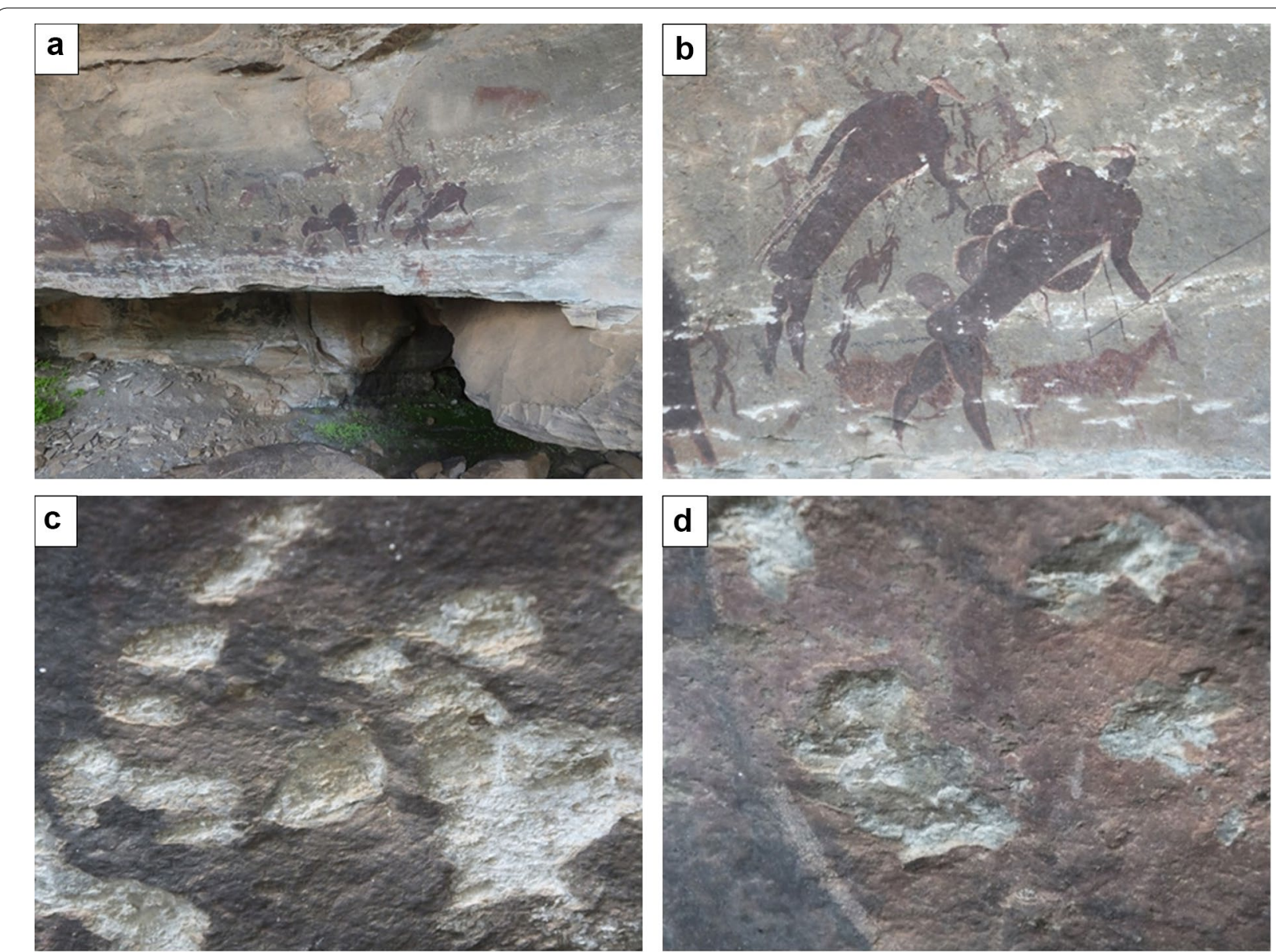

Fig. 10 a Overview of the site, $\mathbf{b}$ therianthropes (half-human, half-antelope), hartebeest and hunters with bullet damage, $\mathbf{c}$ close up of bullet damage shot at approximately $135^{\circ}$ angle relative to rock face, $\mathbf{d}$ close up of bullet damage shot at approximately $90^{\circ}$ angle relatively to rock face 

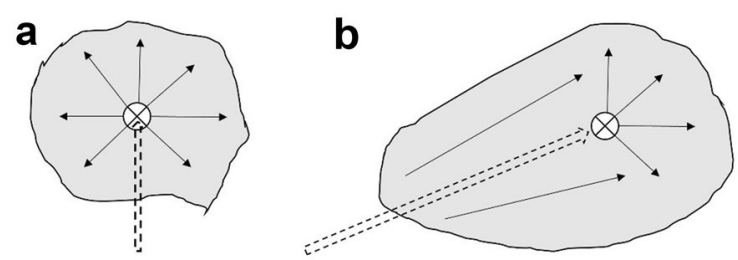

Fig. 11 a Bullet impact at $90^{\circ}$ relative to the rock face, related to Fig. $10 \mathrm{~d}$. $\mathbf{b}$ Bullet impact at $135^{\circ}$ relative to the rock face, related to Fig. $10 \mathrm{c}$

a stronghold of the Republicans, for 2.5 years from July 1936 to March 1939. Regular skirmishes between troops left their mark on the city. Examples of this include the ballistic impacts on the 18th century Alcalá Gate (see Fig. 12) which superimpose on previous ballistic damage generated during the Peninsula War in the 19th century.

The case study discussed here, the School of Medicine of the Complutense University of Madrid, represents not only this 20th century damage and its associated increase in ballistic impact power, but also provides a very good baseline for impact measurements; this war damage was inflicted very soon after the completion of the building. Therefore, ballistic damage was not superimposed to any previous weathering process and any differences in deterioration behaviour can therefore be attributed to ballistic damage. This is in contrast with the previous case studies where the sites had been created centuries before ballistic impacts hit their surfaces, and where weathering inheritance might alter the long-term response of the stone to ballistic impacts $[10,52]$.

\section{Case study 4: Complutense University of Madrid}

The example of the Spanish Civil War once again affords a challenging case for assessing the challenges of ballistic impacts within cultural heritage conservation. Today, the School of Medicine of the Complutense University is designated as being for the "Good of Cultural Interest" (which is the highest level of protection for cultural heritage in Spain) by virtue of its central role in the War. The site itself has a long history. In 1836, the 15th century Alcalá University was moved to Madrid. A new campus in the northwest area of Madrid was planned in the late 1920s and Miguel de los Santos Nicolás was
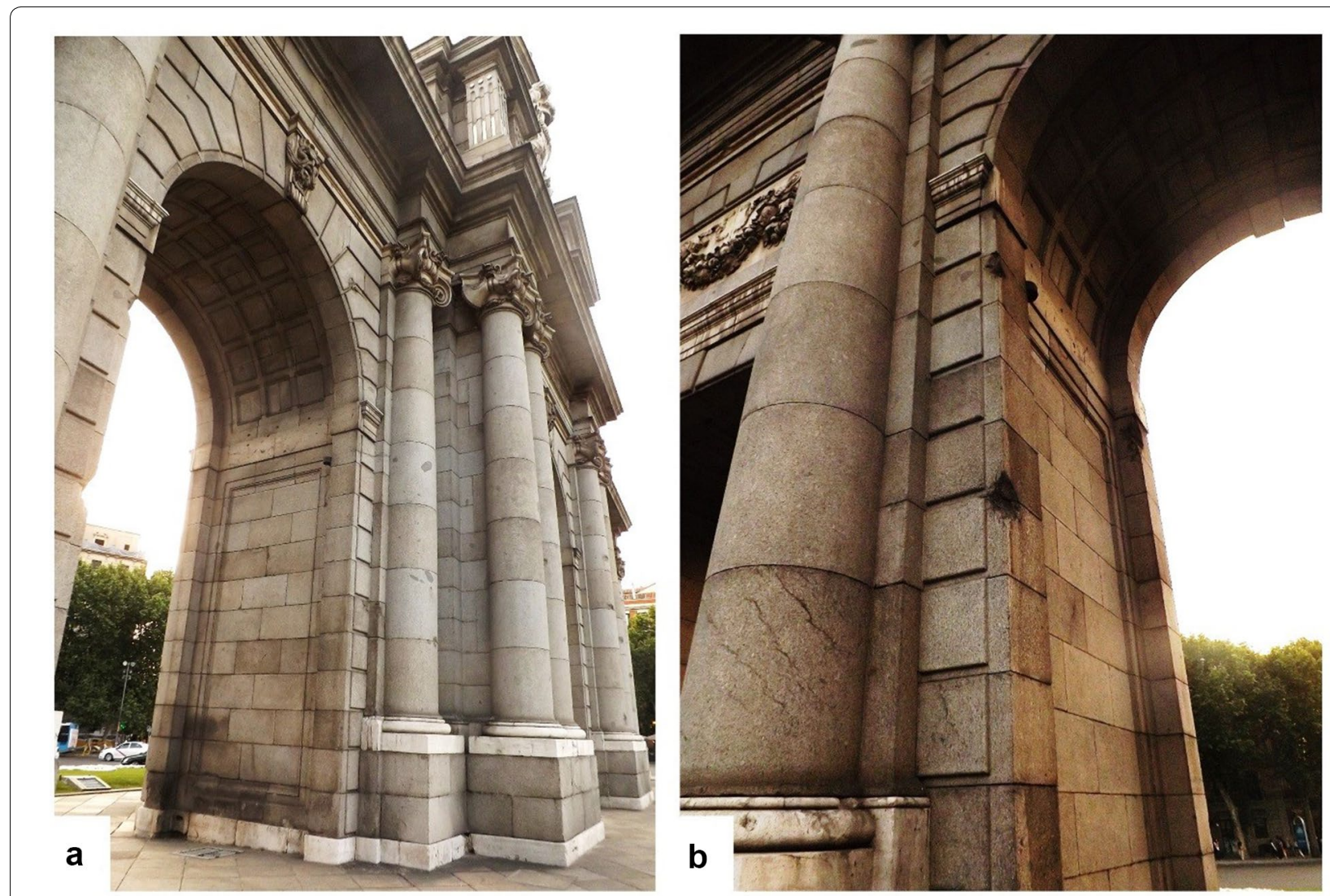

Fig. 12 a Impacts on decorative pillars of the Alcalá Gate and $\mathbf{b}$ ballistic damage to corners of arch 


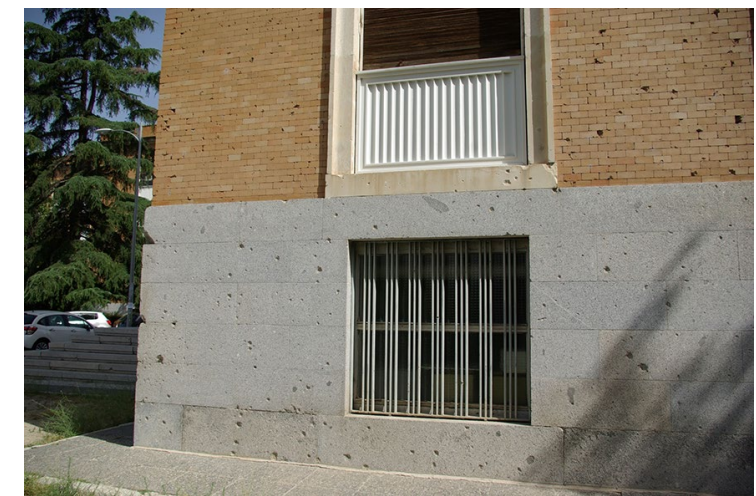

Fig. 13 Overall view of an area of the building showing ballistic impacts

commissioned as the architect of several buildings in this new Campus, including the School of Medicine [53]. The School of Medicine was built between 1930 and 1935 and the Spanish Civil War commenced shortly after the building was finished. The university campus was assaulted between 15 and 18 November 1936 and was part of the battlefront throughout the rest of the war (1936-1939). Consequently, the building was severely damaged. Between 1941 and 1945 the damaged sections of the building were repaired, or where necessary rebuilt, by Miguel de Los Santos, incorporating bullet and shrapnel impacts across the whole building façades (see Fig. 13).

The building is made mainly of brick, with the plinth, window ledges and other decorations made of limestone. In this case study, we focussed on the window ledges (Fig. 14), which are built out of "Almorqui" stone from Alicante, east Spain, which was a popular stone type in

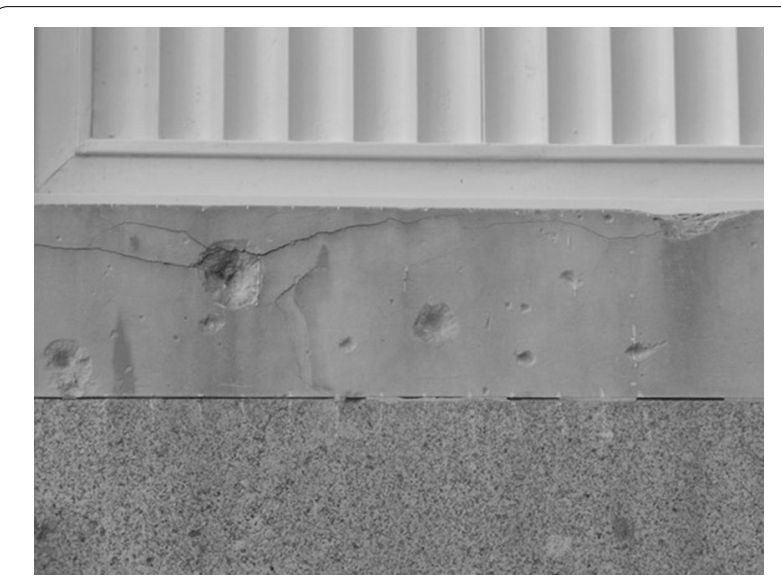

Fig. 14 Impacts of different sizes in a window ledge. Smaller ones, which are likely the result of small size shrapnel, show inside granular disaggregation, while larger ones, coming likely from either rifles or large steel shrapnel, flaking, scaling and loss of fragments
Madrid during the 19th and 20th century. Almorqui stone is a granular porous $(\sim 20 \%$ porosity) biomicrite with up to $10 \%$ of terrigenous components (mainly quartz and clay minerals) as measured in an earlier study by Fort et al. [54]. This area was chosen, as granular biomicrite resembles in both appearance and properties to building sandstone found in previous cases studies.

Recent conflicts tend to involve a wider variety of armament and ammunition, thereby increasing the variability and complexity of contemporary ballistic damage. This case study displays a mixture of impacts coming from bullet impacts (mainly from Mauser M1893 rifles, though it is possible that other rifles may have been added on an impromptu basis to the arsenal of the fighters) and shrapnel impacts from nearby bomb explosions. Shrapnel fragments include lead balls as well as steel fragments of different shapes and sizes. This contrasts with the previous case studies in which all projectiles impacting on stone came from the same source and were similar in size. Therefore, a key issue at this site is the relationship between impact size and resulting damage, which is quantified here.

\section{Methodology}

Three damaged window ledges were selected to characterize the mechanical properties of the areas affected by impacts. Ultrasound Pulse Velocity (UPV) was measured with a CNS electronics Pundit portable ultrasonic test equipment, which can detect a reduction in stone strength even when no deterioration is visible at surface level [55]. While UPV investigations were attempted at case studies 1 and 2, it was not possible to obtain measurements on those sites due to interference by metal reinforcement structures within the stonework, such as pinning, which interfered with the signal. It was, however, successfully applied in this case study.

Leeb rebound hardness was measured using similar methodology to the previous case studies (Equotip 3 with D-type probe). In addition to measurements on the damaged ledges 30 measurements were taken on an undamaged window ledge to obtain baseline values of these properties.

The size of 30 impacts identified in the damaged areas was recorded, with size of impact calculated as an ellipsoid according to longest horizontal and vertical axis. UPV and surface hardness (Leeb) measurements were taken inside each impact to compare the values with the average of undamaged ledge and test how the size of the impact affected compaction and internal damage. Measurements were taken in a $100 \times 20 \mathrm{~cm}$ area, so different sizes of impacts were measured. Measurements were taken using a grid with a spacing of $6 \mathrm{~cm}$ (horizontal) 
and $3 \mathrm{~cm}$ (vertical). UPV was measured in each point of the grid with $1 \mathrm{MHz}$ transducers, plasticine as contact medium, and a constant spacing between transducers of $3 \mathrm{~cm}$. Leeb hardness was measured as the average of three impacts for each point of the grid.

\section{Results}

Leeb values, representing surface hardness, have been plotted against impact size (Fig. 15) using undamaged stone as the benchmark (0). At first sight, there is no clear correlation between Leeb value and impact size, although smaller impacts (less than $6 \mathrm{~cm}^{2}$ ) show more variable behaviour than larger ones. The total average values for all the impacts displayed a high standard deviation showing that there was no common behaviour for all the impacts. This is likely caused by the above-mentioned coexistence of rifle and shrapnel impacts, as well as the possibility of short-range impacts of small projectiles causing a similar size impact to long-range larger projectiles.

In smaller impacts the surface exhibits similar compaction patterns to those observed in the older, lower force impacts demonstrated in Case Studies 1 and 2, strengthening the assumption that smaller impacts are caused by lead shrapnel similar to musket ammunition. Therefore, this case study illustrates the differences shown in Fig. 5 (Case Study 1) between energy density and dispersal of rifle impacts in which damage penetrates deeper in the stone, and "low impact" lead bullets in which the majority of the damage associated with the impact is released on the surface. This stress release at surface level is likely to exploit pre-existing weaknesses, such as bedding planes, to dissipate outwards. This follows the principles shown by Barauskas and Abraitiene [56] who mapped surface deformation around the impact site in multilayer fabrics.

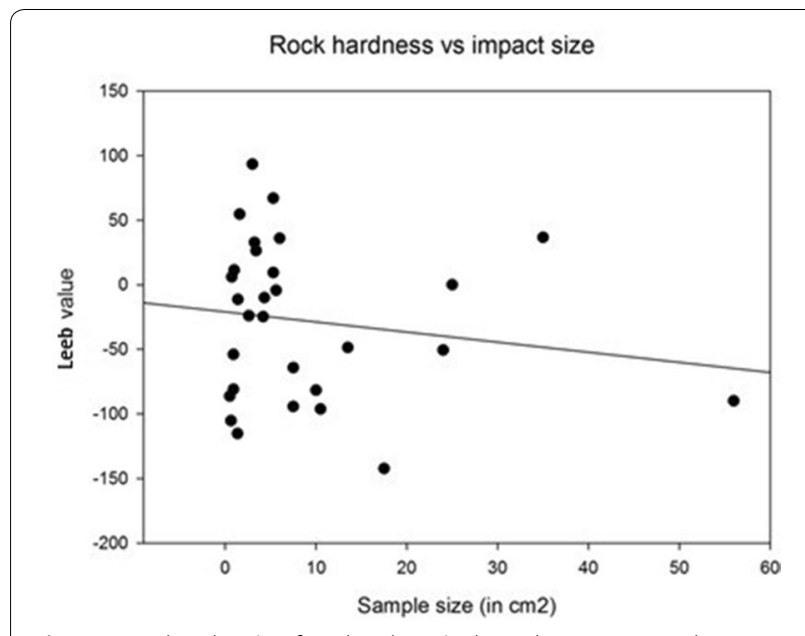

Fig. 15 Leeb value (surface hardness) plotted against sample size
As it is likely that these impacts have deteriorated subsurface structural stability, rather than just surface and near-surface deterioration as measured by the Equotip Leeb values, additional Ultrasound Pulse Velocity (UPV) were taken which detect voids and fissures. As Fig. 16 illustrates, there is a visible logarithmic correlation between the impact area and UPV, which fits well with the visual examination of impacts: the smallest ones show some dusting or granular disaggregation within, and as the grow larger, material loss scale also increase, going from granular disaggregation, through flaking, to eventually show losses in small chunks related to fracture formation through energy dissipation. Where impacts had taken place close to the top surface of the ledge, thereby lacking confining pressure from the top, fracture development was more obvious which is also reflected in lower values than expected according to the logarithmic trend line.

To further this potential relationship between subsurface deterioration and impact size and placement, the results were mapped using ArcGIS and 3D scanning (Fig. 17).The results show large horizontal and perpendicular to the surface factures, which are the main "bulk" changes in these ledges. These window ledges are confined laterally but unconfined vertically on the top, and that affects the fracturing pattern of the whole ledge. Most fractures are horizontal and located on the top third of the ledge, regardless of the size and position of impacts, which likely is related to the lack of confinement of the ledges on the top face. Larger shots also have a fracturing pattern which includes fractures parallel to the external surface. These are often concealed, but are here detected with UPV.

Unlike the results reported in case studies 1 and 2, where damage appeared to be restricted to the surface and near-surface in the area immediately surrounding the impact zone, stress generated by the Madrid impacts travels through the surface and causes deterioration away from the initial impact zone. This fundamental change in damage pattern, causing wider spread subsurface structural damage through fracture network development,

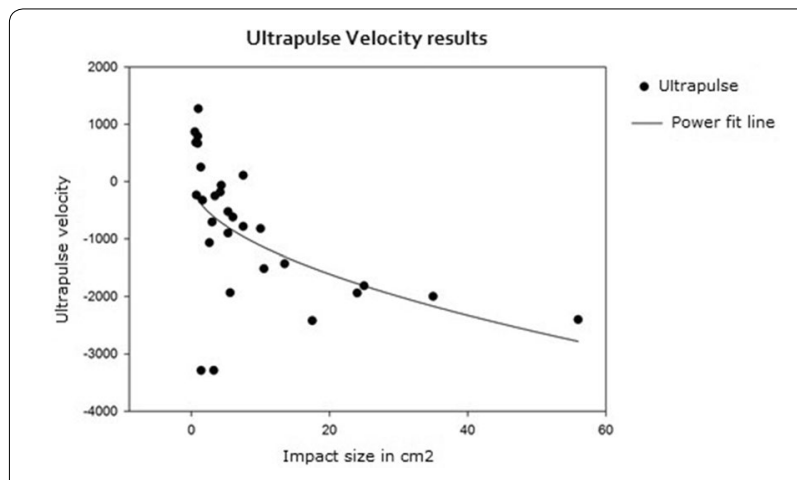

Fig. 16 UPV measurements plotted against impact size 


\section{SCHOOL OF MEDICINE. MADRID. SPAIN \\ LEGDE WINDOW 2 SOUTH PAVILION \\ SHRAPNEL IMPACTS}

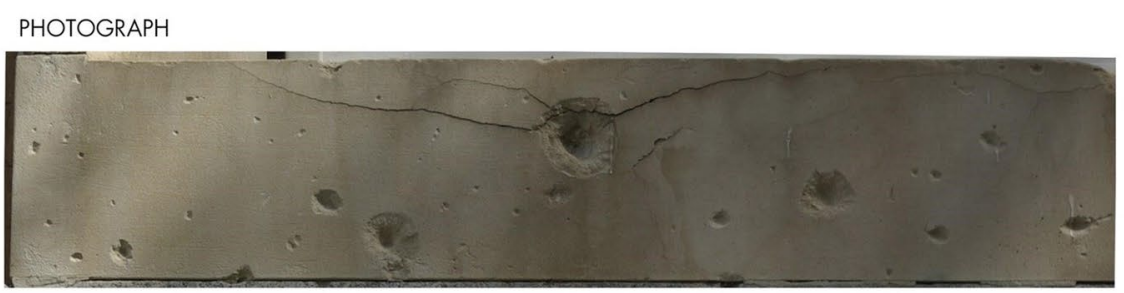

POINT CLOUD
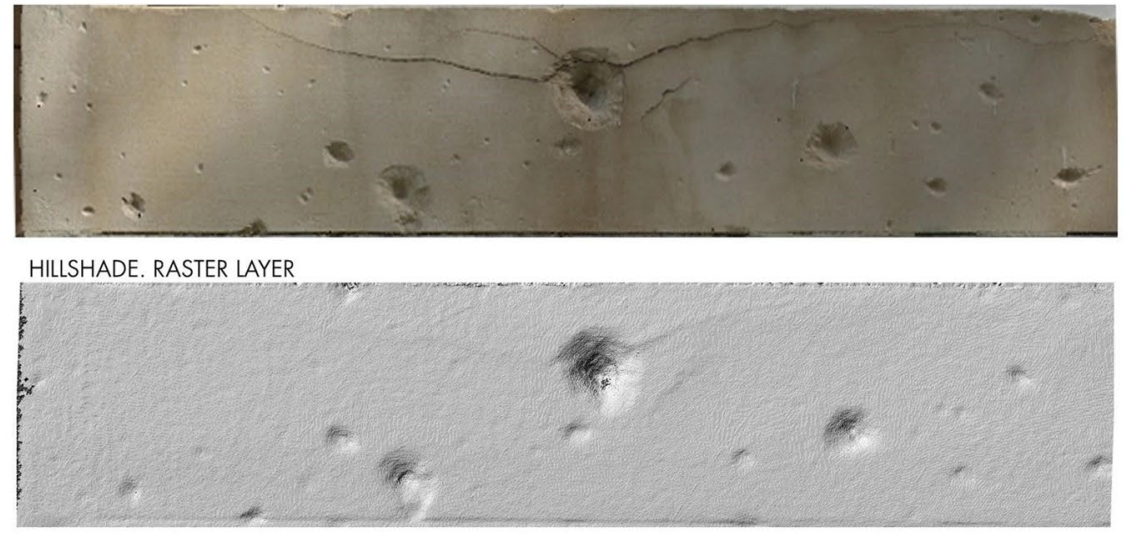

UPV
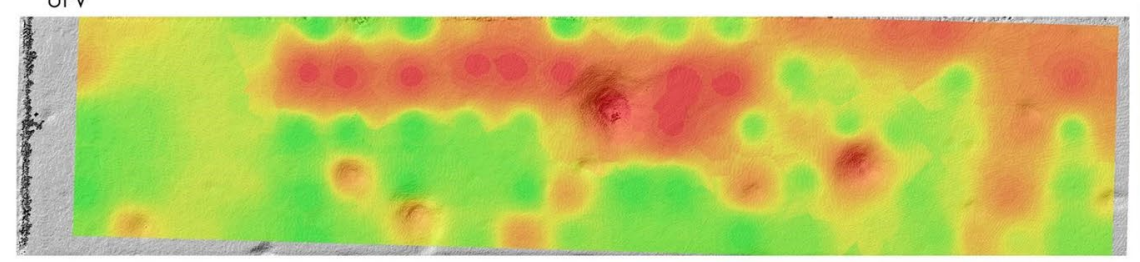

$3736(\mathrm{~m} / \mathrm{s})$

LEEB

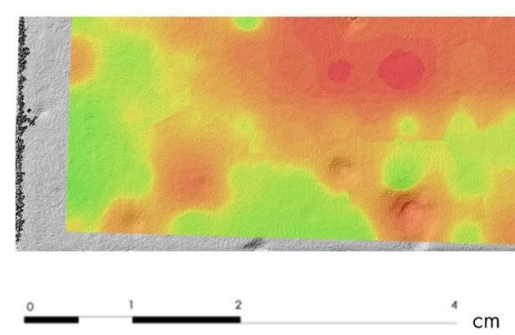

Fig. 17 Measurement maps of ledge showing the distribution of UPV and Leeb values in relation to visible impacts

indicates the changing nature of the deterioration threat to heritage that more recent ballistic impacts pose. These fracture networks can not only deteriorate the strength of the stone at time of impact but can also be exploited by weathering processes for more rapid deterioration of the stone on the medium- and long-term. While historic lowenergy impacts, such as those illustrated in case studies 1 and 2, can exhibit very little long-term deterioration of the wider stone block and give little cause for concern we need to fundamentally change the way we approach conservation of ballistic impacts to reflect the energy and penetrative nature of contemporary bullet impacts.

\section{Discussion}

These case studies illustrate a temporal range of impacts, namely the 17th, 19th and 20th centuries, which represent the ongoing development of ballistic weaponry. In 
particular, the contrast between the rounded musket balls (Case Studies 1 and 2) and the more modern weaponry of the 20th century highlights the increasing intensity of the ballistic impacts. In addition to this, modern warfare is characterised by a more extensive mixture of coexisting weaponry. Where previously some damage or even compaction of the surface is associated with musket ball impacts, Case Study 4 has revealed the resonating impact further into the stone, creating far more complicated fracture networks and energy dissipation than might be visible on the surface. This increasingly penetrating nature of ballistic missiles, both in terms of the bullets themselves and the weaponry used to shoot them, is a cause for grave concern for the future conservation of damaged heritage in conflict areas; if ballistics continue to increase in strength both in terms of energy and energy density at point of impact as well as increasingly efficient penetration of a material, it will be increasingly difficult to stabilise heritage post-conflict.

The issue is further complicated by the increasingly high profile of cultural destruction as an act of establishing geographical and cultural dominance, as seen in recent conflicts led by Daesh/So-Called IS. As illustrated and quantified in this article, the targeted, as well as incidental destruction, has become more effective and widespread with the integration of artillery ingrained into tactics and army provisions many centuries ago and has increased in destruction potential at pace with weapon development. While the impacts described in Case Studies 1 and 2 could be considered a relatively harmless potential deterioration enhancement, Case Study 4 illustrates that, 70 years ago, guns were already capable of creating substantial sub-surface destabilisation of stonework. This begs the question: what damage can weaponry now inflict? While little is known of the material deterioration of heritage sites subjected to contemporary ballistic impacts, Mol et al. [10] reported that even smaller impacts could now create substantial subsurface deformation. The in situ data presented in Case Study 4 builds on the results presented in the experimental study [10], and underlines the shift from the superficial damage created by musket balls (case studies 1 and 2) and percussion-lock muskets (Case Study 3) to far more destructive artillery in recent conflict. There are therefore two lessons that need to be drawn from the case studies laid out in this study:

1. Targeted and incidental (cross-fire) destruction of culture is not a new phenomenon, in fact ballistic scars can be found on multiple continents ranging many conflicts and spanning centuries, as illustrated by our case studies. These impacts require careful consideration in conservation strategies, in terms of the relative strength of the impact (Case Studies 1 through 4), the clustering of impacts (Case Studies 1 and 4), and the angle of impact (Case Study 3).

2. The enhanced threat to built cultural heritage in contemporary conflicts lies in the increasingly-destructive penetrative of nature of ballistics. While Case Study 1 showed relative strengthening of the surface in singular impact sites (but not in clustered impact sites), the far more destructive artillery of Case Study 4 showed a much more noticeable deterioration throughout the stonework. This increasing subsurface damage beyond the immediate impact zone needs to be taken into account when assessing damage to both historic and contemporary sites. In addition, these measurements can be seen as a warning of the continuing development of weaponry and the effect that ballistics will have on heritage stonework in future conflicts.

In this light, it is therefore important that the scientific community continues to explore the impact of ballistics on stone surfaces, building on the work presented here to quantify the impact of conflict on stonework strength and deterioration. While it might seem obvious that older impacts from lower-strength artillery create less damage, this research has identified the complexities associated with multiple impacts and has also provided the first quantification of ballistic impacts on historic stonework.

\section{Conclusions}

As illustrated by the case studies, the impact of ballistics on build heritage is of increasing concern; the development of artillery since the $1600 \mathrm{~s}$ shows the increasingly destructive trajectory of ballistics development. To fully understand the threat that historic as well as contemporary ballistic impacts pose to build heritage we therefore need to take into account when the conflict took place, e.g. how variable and penetrative the ballistics were at the time, and use this knowledge to extrapolate the likely presence of subsurface deterioration of the stone which is not visible from the surface. This study presents the first quantification of the impact of ballistics on historic stonework and shows the accelerating damage curve associated with the development of artillery over the centuries.

\section{Abbreviations}

3D: three dimensional; RSH: rock surface hardness; GIS: geographical information system-ArcGIS indicates commercial software system; KZN: KwaZuluNatal; UPV: ultrasound pulse velocity. 


\section{Authors' contributions}

LM collected the data for case studies 1, 2 and 3 and wrote the manuscript. MG-H collected the data for case study 4 and contributed to the manuscript. Both authors read and approved the final manuscript.

\section{Author details}

${ }^{1}$ Department of Geography and Environmental Management, University of the West of England, Frenchay Campus, Coldharbour Lane, Bristol BS16 1QY, UK. ${ }^{2}$ Department of Geology and Geochemistry, Universidad Autonoma de Madrid, Madrid, Spain. ${ }^{3}$ Instituto de Geociencias (CSIC, UCM), Madrid, Spain.

\section{Acknowledgements}

The authors are very grateful for the goodwill of Prof John Lewin and the Powick Church Trust, as well as St Mary the Virgin and their restoration employers for facilitating access to the premises. We thank Dr Laura López and Geomateriales 2 S2013/MIT-2914 for assistance with GIS analysis and support for Case Study 4. We also want to thank Prof Heather Viles for the loan of laboratory equipment used to carry out this research. We are grateful for the assistance of Dr Mark Williams in improving the historical narrative of this manuscript. Finally, we want to thank two anonymous reviewers whose helpful suggestions and comments were very valuable in improving this manuscript.

\section{Competing interests}

To the best of the author's knowledge there are no competing interests associated with this research.

\section{Availability of data and resources}

All data is available directly from the authors on request. Please contact the corresponding author for access.

\section{Ethics approval and consent to participate}

Not applicable.

\section{Funding}

This research was carried out under Leverhulme Trust Research Grant

RPG-2017-408.

\section{Publisher's Note}

Springer Nature remains neutral with regard to jurisdictional claims in published maps and institutional affiliations.

Received: 3 January 2018 Accepted: 28 May 2018

Published online: 05 June 2018

\section{References}

1. Kousser R. Destruction and memory on the Athenian Acropolis. Art Bull. 2009;91(3):263-82.

2. Merryman JH. Two ways of thinking about cultural property. Am J Int Law. 1986;80(4):831-53.

3. Winter T. Post-conflict heritage and tourism in Cambodia: the burden of Angkor. Int J Heritage Stud. 2008;14(6):524-39.

4. Giblin JD. Post-conflict heritage: symbolic healing and cultural renewal. Int J Heritage Stud. 2014;20(5):500-18.

5. Gamboni D. The destruction of art: iconoclasm and vandalism since the French Revolution. Islington: Reaktion books; 1997.

6. Isakhan B, Zarandona JAG. Layers of religious and political iconoclasm under the Islamic State: symbolic sectarianism and pre-monotheistic iconoclasm. Int J Heritage Stud. 2018;24(1):1-16.

7. Singer GG. 2015. ISIS'War on cultural heritage and memory. Centro De Estudios De Historia Del Antiguo Oriente (CEHAO) Pontifical Catholic University of Argentina. http://ukblueshield.org.uk/wp-content/uploa ds/2015/06/Singer-Isis_Against_World_Heritage.pdf. Accessed 27 Sept 2017

8. Zarandona JAG, Albarrán-Torres C, Isakhan B. Digitally mediated iconoclasm: the Islamic State and the war on cultural heritage. Int J Heritage Stud. 2018:24(6):649-71.
9. Smith C, Burke H, de Leiuen C, Jackson G. The Islamic State's symbolic war: Da'esh's socially mediated terrorism as a threat to cultural heritage. J Soc Archaeol. 2016;16(2):164-88.

10. Mol L, Gomez-Heras M, Brassey C, Green O, Blenkinsop T. The benefit of a tough skin; bullet holes, weathering and the preservation of heritage. $\mathrm{R}$ Soc Open Sci. 2017;4:160271.

11. Frangipane A. From spolia to recycling: the reuse of traditional construction materials in built heritage and its role in sustainability today: a review. In: Prykril, et al., editors. Sustainable Use of Traditional Geomaterials in Construction Practice. 416th ed. London: Geological Society; 2016. p. 23-33.

12. Walter J. Popular iconoclasm and the politics of the parish in eastern England. His J. 2004;47(2):261-90.

13. Budd J. Rethinking iconoclasm in early modern England: the case of the Cheapside Cross. J Early Mod Hist. 2000;3(3-4):379-404.

14. Askew RMC. Political iconoclasm: the destruction of Eccleshall Castle during the English Civil Wars. Post Mediev Archaeol. 2016;50(2):279-88.

15. Parishes. Powick a history of the county of Worcester. Br Hist Online. 1924:4:184-92

16. Atkin M. Worcester 1651. Barnsley: Pen and Sword; 2008

17. O'Carroll D. Change and continuity in weapons and tactics 1594-1691. In: Lenihan $\mathrm{P}$, editor. Conquest and resistance: war in seventeenth-century Ireland. Koninklijke Brill NV: Leiden; 2001. p. 211-53.

18. Aoki H, Matsukura Y. A new technique for non-destructive field measurement of rock-surface strength: an application of the Equotip hardness tester to weathering studies. Earth Surf Process Landforms. 2007:32(12):1759-69.

19. Betts MW, Latta MA. Rock surface hardness as an indication of exposure age: an archaeological application of the Schmidt Hammer. Archaeometry. 2000;42(1):209-23.

20. McCarroll D. The Schmidt hammer, weathering and rock surface roughness. Earth Surf Process Landforms. 1991;16(5):477-80.

21. Mol L, Viles $H$. The role of rock surface hardness and internal moisture in Tafoni development in sandstone. Earth Surf Process Landforms. 2012;37(3):301-14.

22. Viles H, Goudie A, Grab S, Lalley J. The use of the Schmidt Hammer and Equotip for rock hardness assessment in geomorphology and heritage science: a comparative analysis. Earth Surf Process Landforms. 2011;36(3):320-33.

23. Coombes MA, Feal-Pérez A, Naylor LA, Wilhelm K. A non-destructive tool for detecting changes in the hardness of engineering materials: application of the Equotip durometer in the coastal zone. Eng Geol. 2013;167:14-9.

24. Pérez Alberti A, Gomes A, Trenhaile A, Oliveira M, Horacio J. Correlating river terrace remnants using an Equotip hardness tester: an example from the Miño River, northwestern Iberian Peninsula. Geomorphology. 2013:192:59-70.

25. Wilhelm K, Viles H, Burke Ó. Low impact surface hardness testing (Equotip) on porous surfaces - advances in methodology with implications for rock weathering and stone deterioration research. Earth Surf Process Landforms. 2016:41(8):1027-38.

26. Verwaal W, Mulder A. Estimating rock strength with the Equotip hardness tester. Int J Rock Mech Min Sci Geomech Abstracts. 1993;30(6):659-62.

27. Hack HRGK, Hingira J, Verwaal W. Determination of discontinuity wall strength by Equotip and ball rebound tests. Int J Rock Mech Min Sci Geomech Abstracts. 1993;30(2):151-5.

28. Ruedrich J, Bartelsen T, Dohrmann R, Siegesmund S. Moisture expansion as a deterioration factor for sandstone used in buildings. Environ Earth Sci. 2011:63(7-8):1545-64.

29. Perry SH, Duffy AP. The short-term effects of mortar joints on salt movement in stone. Atmos Environ. 1997;31(9):1297-305.

30. Miller DP. Ballistics of 17th Century Muskets. M.Sc. Thesis, Cranfield University, 2010.

31. Bellamy RF. Evolution of wound ballistics: a brief history. Conventional warfare: ballistic, blast and burn injuries. In: Bellamy RF, Zajtchuk R, Buescher TM, editors. Textbook of military medicine: warfare, weaponry, and the casualty. Bethesda: Walter Reed Army Institute of Research, Walter Reed Army Medical Center; 1991.

32. Berryman $\mathrm{H}$, Smith $\mathrm{O}$, Symes $\mathrm{S}$. Diameter of cranial gunshot wounds as a function of bullet calibre. J Forensic Sci. 1991:40(5):751-4. 
33. Yankelevsky DZ. Local response of concrete slabs to low velocity missile impact. Int J Impact Eng. 1997;19(4):331-43.

34. Donagan B. Did ministers matter? War and religion in England, 16421649. J Br Stud. 1994;33(2):119-56.

35. Varley FJ. The Siege of Oxford: an account of Oxford during the Civil War 1642-1646. Oxford: Oxford University Press; 1932.

36. Spraggon J. Puritan iconoclasm during the English Civil War. Woodbridge: The Boydell Press; 2003.

37. University Church. Architecture. http://www.universitychurch.ox.ac.uk/ heritage/architecture/. Accessed 22 Apr 2018.

38. Historic England List Entry 1047275 (12/01/1954) Church of St. Mary the Virgin. https://historicengland.org.uk/listing/the-list/list-entry/1047275. Accessed 22 Nov 2017.

39. Oxford history the high University church of St. Mary the Virgin. http:// www.oxfordhistory.org.uk/high/tour/north/stmarys_church.html. Accessed 22 Apr 2018.

40. Freire-Lista DM, Fort R, Varas-Muriel MJ. Thermal stress-induced microcracking in building granite. Eng Geol. 2016;206:83-93.

41. Mol L, Viles H. Geoelectric investigations into sandstone moisture regimes: implications for rock weathering and the deterioration of San Rock Art in the Golden Gate Reserve, South Africa. Geomorphology. 2010;118(3-4):280-7.

42. Hall K, Arocena JM, Boelhouwers J, Liping Z. The influence of aspect on biological weathering of granites: observations from the Kunlun Mountains, China. Geomorphology. 2005;67:171-88.

43. De'Gennaro M, Calcaterra D, Cappelletti P, Langella A, Morra V. Building stone and related weathering in the architecture of the ancient city of Naples. J Cult Heritage. 2000;1 (4):399-414

44. Přikryl R, Weishauptová Z, Novotná M, Přikrylová J, Št'astná A. Physica and mechanical properties of the repaired sandstone ashlars in the facing masonry of the Charles Bridge in Prague (Czech Republic) and an analytical study for the causes of its rapid decay. Environ Earth Sci. 2011;63(7-8):1623-39.

45. Taruvinga $P$, Ndoro $W$. The vandalism of the Domboshava rock painting site, Zimbabwe. Conserv Manag Archaeol Sites. 2003;6:3-10.
46. Bevan R. The destruction of memory: architecture at war. London: Reaktion books; 2007

47. Tournié A, Prinsloo LC, Paris C, Colomban P, Smith B. The first in situ Raman spectroscopic study of San rock art in South Africa: procedures and preliminary results. J Raman Spectrosc. 2011:42:399-406.

48. Meiklejohn KI, Hall K, Davis JK. Weathering of rock art at two sites in the KwaZulu-Natal Drakensberg, southern Africa. J Archaeol Sci. 2009;36:973-9.

49. Saks D. Durnford, 'Long Belly' and the farce at the pass. South Afr Military Hist Soc Military Hist J. 2007;14(2) ISSN 0026-401660. http://samilitary history.org/vol142ds.html.

50. Bourquin S. Colonel A.W. Durnford. South Afr Military Hist Soc Military Hist J. 1985;6(5) ISSN 0026-4016. http://samilitaryhistory.org/vol065sb. html.

51. Atmore A, Sanders P. Sotho arms and ammunition in the nineteenth century. J Afr Hist XII. 1979;4:535-44.

52. Goudie AS, Wright E, Viles HA. The roles of salt (sodium nitrate) and fog in weathering: a laboratory simulation of conditions in the northern Atacama Desert, Chile. CATENA. 2002;48(4):255-66.

53. Chias Navarro P. La Ciudad Universitaria de Madrid. Génesis y Realización. 1st ed. Madrid: Editorial de la Universidad Complutense; 1986.

54. Fort R, Bernabeu A, García del Cura MA, López de Azcona MC, Ordóñez S, Mingarro F. Novelda Stone: widely used within the Spanish architectural heritage. Materiales de Construccion. 2002;52(266):19-32.

55. Myrin M, Malaga K. A case study on the evaluation of consolidation treatment of Gotland sandstone by use of ultrasound pulse velocity measurements. In: Fort R, de Alvarez Buergo M, Gomez-Heras M, Vazquez-Calvo C, editors. Heritage, weathering and conservation. 2nd ed. London: Taylor and Francis Group plc; 2006. p. 749-56.

56. Barauskas R, Abraitiene A. Computational analysis of impact of a bullet against the multilayer fabrics in LS-DYNA. Int $\mathrm{J}$ Impact Eng. 2007;34(7):1286-305.

\section{Submit your manuscript to a SpringerOpen ${ }^{\circ}$ journal and benefit from:}

- Convenient online submission

- Rigorous peer review

- Open access: articles freely available online

- High visibility within the field

- Retaining the copyright to your article

Submit your next manuscript at $\boldsymbol{\nabla}$ springeropen.com 